\section{Analisis perbandingan efektifitas aturan dalam Kitab Undang Undang Hukum Pidana lama dan Revisi Kitab Undang Undang Hukum Pidana (khususnya dalam pasal perzinahan)}

oleh :

\section{Nur Shabrina Sinulingga ${ }^{1}$ \\ (nur.sinulingga@gmail.com)}

\begin{abstract}
The Criminal Code (KUHP) which is currently in force in Indonesia is a legacy that is still inherited from the Netherlands, so some of the contents of the Article are still incompatible with the culture that developed in Indonesia. One example of the definition of adultery in the Criminal Code is a marital relationship which is committed by a party that one or both are still bound in marriage. Of course this is very contrary to the culture that exists in Indonesia with a majority Muslim population. Indonesian legal experts have drafted the new Criminal Code since 50 (fifty) years ago, then after waiting all the time, finally in 2019, there is a strong discourse that the DPR (House of Representatives) will ratify the new Criminal Code. One of the revised articles in the RKUHP (draft of the Criminal Code) is this adultery article. However, this Article is one that is also a matter of controversy and much opposition.

The old KUHP rules especially those relating to adultery are not in accordance with the culture that exists in Indonesia, so that frequently the act of adultery that actually disturbs the public cannot be tried as expected, but in the current development there are also many parties who consider the notion of adultery in the new KUHP too in entering into the private affairs of the Indonesian people they assume the State should not enter into a very private section.

The legal basis that can be done is a legal basis that is in accordance with that contained in the Criminal Code
\end{abstract}

Keywords: Criminal Code, Adultery
Abstrak

Kitab Undang Undang Hukum pidana (KUHP) yang berlaku saat ini di Indonesia merupakan peraturan yang masih warisan dari Belanda, sehingga beberapa isi Pasal nya masih ada yang tidak bersesuaian dengan kebudayaan yang berkembang di Indonesia. Salah satu contohnya pengertian perzinahan dalam KUHP adalah hubungan suami istri yang dilakukan oleh pihak yang salah satu atau keduanya masih terikat dalam pernikahan. Tentu ini sangat bertentangan dengan budaya yang ada di Indonesia dengan mayoritas penduduk Muslim. Para ahli hukum Indonesia telah merancang Kitab Undang Undang Hukum Pidana yang baru sejak 50 (lima puluh) tahun yang lalu, kemudian atas penantian panjang tersebut akhirnya pada tahun 2019 ada wacana kuat bahwa DPR (Dewan Perwakilan Rakyat) akan mengesahkan KUHP yang baru. Salah satu pasal yang direvisi dalam RKUHP adalah pasal perzinahan ini. Namun, Pasal ini menjadi salah satu yang juga menjadi kontroversi dan banyak mengalami penentangan.

Aturan KUHP lama khususnya yang berkaitan dengan perzinahan tidak sesuai dengan budaya yang ada di Indonesia, sehingga seringkali perbuatan perzinahan yang sesungguhnya meresahkan masyarakat tidak dapat diadili sesuai dengan yang diharapkan, namun dalam perkembangan jaman saat ini banyak juga pihak yang beranggapan pengertian perzinahan dalam KUHP baru terlalu dalam masuk kedalam urusan pribadi masyarakat Indonesia mereka menganggap Negara harusnya tidak masuk sampai keranah sangat pribadi.

Dasar hukum yang dapat dilakukan merupakan dasar hukum yang seusai dengan yang terdapat dalam Kitab Undang-Undang Hukum Pidana

Kata Kunci : Kitab Undang Undang Hukum Pidana, Perzinahan

\footnotetext{
${ }^{1}$ Dosen Universitas Al-Azhar Medan
} 
Media Komunikasi dan Informasi Hukum dan Masyarakat

\section{PENDAHULUAN}

Indonesia adalah Negara dengan jumlah penduduk muslim terbesar di dunia. Hal ini menunjukkan betapa besar pengaruh Islam dalam keseharian masyarakat Indonesia. Mulai dari pentingnya label halal dalam suatu produk, kebijakan ekonomi syariah misal dengan adanya perbankan syariah dll, hingga diberlakukannya hukum Islam dibeberapa kasus di daerah istimewa yaitu Aceh, sampai pada diberlakukannya Kompilasi Hukum Islam dan banyak lainnya.

Hukum di Indonesia tidak dapat dipungkiri juga banyak yang dipengaruhi oleh hukum barat, selain karena Indonesia adalah bagian dari organisasi Internasional sehingga memiliki kewajiban untuk meratifikasi suatu aturan, juga karena Indonesia dulunya adalah Negara jajahan khususnya pada masa penjajahan kolonial Belanda yang berlangsung sampai ratusan tahun. Hal ini lah yang mendasari sampai saat ini masih banyak hukum Indonesia yang merupakan "warisan" dari kolonial belanda. Sebagian dari hukum "warisan" tersebut dirasa tidak sesuai dengan kebudayaan Indonesia, terlebih Indonesia adalah Negara timur yang sangat menjunjung tinggi adat dan kebudayaan Negara timur.

Salah satu hukum yang tidak sesuai dengan kebudayaan Indonesia, adalah hukum mengenai perzinahan. Pengertian yang tercantum dalam Pasal $284 \mathrm{KUHP}$ jelas bertentangan dengan budaya Indonesia dan juga hukum Islam. Urgensi nilai-nilai hukum Islam dalam peraturan perundang-undangan dimaksudkan untuk mengetahui dan sekaligus memahami manfaat pengimplementasian atau konseptualisasi dari perwujudan nilai-nilai syariat islam sebagai bagian dari nilai-nilai agama dalam peraturan perundang-undangan di Indonesia dalam mewujudkan hukum nasional ${ }^{2}$.

Setelah lebih kurang 50 (lima puluh) tahun para ahli hukum merumuskan Rancangan KUHP baru, maka tibalah pada tahun 2019 ini DPR mengumumkan akan segera mengesahkan Revisi KUHP tersebut. Salah satu aturan yang berubah dalam KUHP baru ini adalah Pasal tentang perzinahan.

Pengertian perzinahan yang baru ini terlihat lebih disesuaikan dengan budaya timur Indonesia dan unsur agama Islam yang merupakan agama mayoritas di Indonesia. Pengertian perzinahan terbaru ini menjadi polemik tersendiri, sebahagian masyarakat menilai bahwa Negara terlalu jauh mencampuri urusan pribadi rakyatnya. Selain itu banyak juga yang mempertanyakan bagaimana nasib hotelhotel yang tidak berbasis syariah, bukankah hotel tersebut menjadi memfasilitasi sebuah perbuatan pidana?. Bagaimana juga wilayah wilayah pariwisata Indonesia yang banyak dikunjungi oleh turis asing yang budaya dan cara pandang nya berbeda terutama mengenai perzinahan ini?

\section{TINJAUAN PUSTAKA}

1. Tinjauan umum mengenai Perzinahan

Dalam hukum Islam telah ditegaskan bahwa perzinahan tidak boleh dilakukan sebagaimana yang tertuang dalam al-Qur'an, yakni:

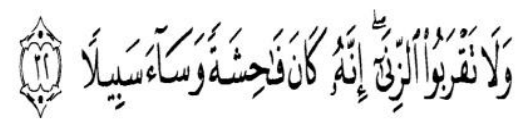

2 Nasaruddin Umar, Urgensi transformasi hukum Islam dalam pemajuan hak asasi manusia di Indonesia, (hunafa : studi islamika, 2015), hlm. 232 
Media Komunikasi dan Informasi Hukum dan Masyarakat

Artinya: Dan janganlah kamu mendekati zina; sesungguhnya zina itu adalah suatu perbuatan yang keji dan suatu jalan yang buruk. (al-Isra :17 (32) )

Zina secara harfiah berarti fahishah, yaitu perbuatan keji. Zina dalam pengertian istilah adalah hubungan kelamin antara seorang lelaki dengan seorang perempuan yang satu sama lain tidak terkait dalam hubungan perkawinan ${ }^{3}$.

Ibnu Rusyd mendefinisikan zina sebagai

persetubuhan yang dilakukan bukan karena

nikah sah atau semu nikah dan bukan karena

pemilikan hamba sahaya ${ }^{4}$.

Dalam KUHP lama perzinahan di atur dalam aturan yakni Pasal 284 :

(1) Diancam dengan pidana penjara paling lama sembilan bulan:

a. Seorang pria yang telah kawin yang melakukan gendak (overaspel), padahal diketahui bahwa pasal 27 BW berlaku baginya:

b. Seorang wanita yang telah kawin yang melakukan gendak, padahal diketahui pasal 27 BW berlaku baginya.

Dalam KUHP lama perzinahan di atur dalam aturan yakni Pasal 417, yaitu :

(1) Setiap orang yang melakukan persetubuhan dengan orang yang bukan suami atau istrinya dipidana karena perzinaa dengan pidana penjara paling lama 1 (satu) tahun atau denda kategori II.

\section{METODE PENELITIAN}

Metode penelitian merupakan cara kerja yang digunakan untuk mengumpulkan data dari objek yang menjadi sasaran dari penelitian. Istilah metode itu sendiri berasal dari bahasa Yunani "methodos" yang berarti cara kerja, upaya atau jalan suatu kegiatan dan pada dasarnya adalah salah satu upaya tersebut

\footnotetext{
${ }^{3}$ Zainuddin Ali, Hukum Pidana Islam, (Jakarta :

Sinar Grafika, 2009), hlm 37

${ }^{4}$ Rahmat Hakim, Hukum Pidana Islam (Fiqh

Jinayah), (Bandung : Pustaka Setia, 2000), hlm 69
}

bersifat ilmiah dalam mencari kebenaran yang dilakukan dengan mengumpulkan data sebagai dasar penentuan kebenaran yang dimaksud ${ }^{5}$.

Metode Penelitian yang dilakukan dalam menyelesaikan Penelitian ini adalah Metode Yuridis Normatif. Penelitian hukum yang dilakukan dengan cara meneliti bahan pustaka atau data sekunder belaka, dapat dinamakan penelitian hukum normatif atau penelitian hukum kepustakaan (disamping adanya penelitian hukum sosiologis atau empiris yang terutama meneliti data primer). Penelitian hukum doktrinal dapat dikatakan sebagai library based focusing on reading and analysis of the primary and secondary materials ${ }^{6}$.

Penelitian hukum normatif adalah penelitian hukum yang mengkaji hukum tertulis dari berbagai aspek teori, sejarah, filosofis, perbandingan, struktur dan komposisi, lingkup dan materi, konsistensi, penjelasan umum Pasal demi Pasal, formalitas dan kekuatan mengikat suatu undang-undang, serta bahasa hukum yang digunakan, tetapi tidak mengkaji aspek terapan atau implementasinya, maka penelitian hukum normatif juga sering disebut "penelitian hukum dogmatik" atau "penelitian hukum teoritis"7.

Bahan-bahan hukum primer dan bahanbahan hukum sekunder tersebut, menurut Peter Mahmud merupakan sumber-sumber penelitian hukum.Bahan hukum primer merupakan bahan hukum yang bersifat autoritatif artinya mempunyai otoritas.Sedangkan bahan-bahan hukum sekunder berupa semua publikasi

\footnotetext{
${ }^{5}$ Koentjoroningrat, Metode-metode Penelitian Masyarakat, (Jakarta : Gramedia, 1992), hlm 22 ${ }^{6}$ Johnny ibrahim, Teori dan Metodologi Penelitian Hukum Normatif, (Malang : Bayumedia, 2008), hlm 46

${ }^{7}$ Soerjono Soekanto, Pengantar Penelitian Hukum, (Jakarta : UI Press, 1984), hlm 42
} 
Media Komunikasi dan Informasi Hukum dan Masyarakat

tentang hukum yang bukan merupakan dokumen-dokumen resmi ${ }^{8}$.

\section{HASIL PENELITIAN \\ PEMBAHASAN}

Konsep tentang tindak pidana perzinaan menurut hukum islam jauh berbeda dengan sistem hukum barat, karena dalam hukum islam, setiap hubungan seksual yang diharamkan itulah zina, baik yang dilakukan oleh orang yang telah berkeluarga maupun yang belum berkeluarga asal ia tergolong orang mukallaf, meskipun dilakukan dengan rela sama rela, hal tersebut tetap merupakan tindak pidana ${ }^{9}$.

Merujuk pada pengertian tersebut diatas, maka dapat diketahui bahwa menurut hukum islam suatu perbuatan dikatakan perzinahan tidak hanya jika dilakukan oleh pasangan yang salah satu atau kedua nya terikat dalam perkawinan melainkan meskipun dilakukan oleh dua pihak yang kedua nya tidak terikat dalam perkawinan juga dikategorikan sebagai sebuah perzinahan.

Dalam kehidupan bermasyarakat di Indonesia, sebagian besar masyarakat Indonesia memahami bahwa pengertian dari perzinahan adalah pengertian yang sesuai dengan hukum islam tersebut. Masyarakat di Indonesia tidak banyak yang mengetahui bahwa pengertian perzinahan yang dicantumkan dalam Kitab Undang-Undang Hukum Pidana adalah

\footnotetext{
${ }^{8}$ Peter Mahmud Marzuki, Penelitian Hukum, (Jakarta : Prenada Media Group, 2009), hlm 32

9 Ahmad Wardi Muslich, Hukum Pidana Islam, ( Jakarta : Sinar Grafika, 2005), hlm 8
}

mengadopsi dari hukum Belanda yang tidak sesuai dengan budaya Indonesia.

Dalam KUHP lama perzinahan di atur dalam aturan sebagai berikut, yakni Pasal 284 : (1) Diancam dengan pidana penjara paling lama sembilan bulan:

a. Seorang pria yang telah kawin yang melakukan gendak (overaspel), padahal diketahui bahwa pasal 27 BW berlaku baginya:

b. Seorang wanita yang telah kawin yang melakukan gendak, padahal diketahui pasal 27 BW berlaku baginya.

Dari isi pasal tersebut diatas dapat kita ketahui bahwa pengertian perzinahan di Indonesia adalah suatu hubungan suami istri yang dilakukan oleh perempuan dan laki-laki yang salah satu atau keduanya masih terikat dalam perkawinan. Sehingga apabila merujuk dari pasal tersebut para pasangan yang melakukan perzinahan dan tidak terikat dalam perkawinan dapat dengan bebas di Indonesia.

Hal ini akan dapat memfasilitasi sex bebas di Indonesia, karena para pasangan khususnya muda mudi yang tidak terikat dalam perkawinan dapat melakukan zinah tanpa takut dapat dikenai sanksi pidana.

Hukuman atau sanksi yang diberikan oleh hukum islam terhadap para pelaku zinah memang tidak dapat diberlakukan di Indonesia, karena sanksi tersebut akan menimbulkan kontroversi dan akan menjadi kasus Hak Asasi Manusia (HAM) sehingga memang sanksi tersebut tidak dapat di adopsi. Namun pengertian dari perzinahan dalam hukum islam tersebut sangat penting untuk dapat diadopsi oleh hukum Indonesia, karena terasa lebih sesuai dengan kebudayaan masyarakat di Indonesia. Selain itu juga untuk menghindarkan perbuatan sex bebas di Indonesia. 
Media Komunikasi dan Informasi Hukum dan Masyarakat

Hukum Islam telah banyak diadopsi oleh hukum Indonesia dan oleh berbagai Negara karena terbukti dapat menyelesaikan berbagai permasalahan hukum yang dirasakan oleh masyarakat. Hal ini terlihat dengan adanya Undang-Undang Nomor 1 Tahun 1974 Tentang Perkawinan, Undang-Undang Nomor 7 Tahun 1989, berlakunya Kompilasi Hukum Islam dan lain sebagainya. Sehingga bukan hal yang baru lagi apabila pengertian perzinahan di dalam KUHP dapat merujuk pada pengertian perzinahan dalam hukum islam.

Setelah perjalanan yang sangat panjang akhirnya wacana pengesahan KUHP baru semakin kuat terdengar akan segera dilakukan pada tahun 2019 ini. Salah satu aturan yang direvisi adalah pengertian perzinahan. Pengertian perzinahan kali ini lebih disesuaikan dengan budaya timur dan Islam yang dianut oleh mayoritas masyarakat Indonesia.

Dalam KUHP lama perzinahan di atur dalam aturan yakni Pasal 417 , yaitu :

(1) Setiap orang yang melakukan persetubuhan dengan orang yang bukan suami atau istrinya dipidana karena perzinaa dengan pidana penjara paling lama 1 (satu) tahun atau denda kategori II.

(2) Tindak Pidana sebagaimana dimaksud pada ayat (1) tidak dilakukan penuntutan kecuali atas pengaduan suami, istri, orang tua, atau anaknya.

Penjelasan mengenai pasal perzinahan ini menerangkan lebih lanjut :

Ayat (1) : yang dimaksud dengan "bukan suami atau istrinya" adalah :

a. Laki-laki yang berada dalam ikatan perkawinan melakukan persetubuhan dengan perempuan yang bukan istrinya;

b. Perempuan yang berada dalam ikatan perkawinan melakukan persetubuhan dengan laki-laki yang bukan suaminya;

c. Laki-laki yang tidak dalam ikatan perkawinan melakukan persetubuhan dengan perempuan, padahal diketahui bahwa perempuan tersebut berada dalam ikatan perkawinan;

d. Perempuan yang tidak dalam ikatan perkawinan melakukan persetubuhan dengan laki-laki, padahal diketahui bahwa laki-laki tersebut berada dalam ikatan perkawinan;

e. Laki-laki dan perempuan yang masingmasing tidak terikat dalam perkawinan melakukan persetubuhan.

Ayat (2) : yang dimaksud dengan "anaknya" dalam ketentuan ini adalah anak kandung yang sudah berusia 16 (enam belas) tahun.

Menurut pengertian tersebut diatas, maka terjadi perubahan pengertian perzinahan tidak lagi hubungan yang dilakukan laki-laki dan perempuan yang salah satu atau keduanya terikat dalam perkawinan, namun pengertian perzinahan yang baru ini menjadi hubungan antara laki-laki dan perempuan baik yang terikat dalam perkawinan maupun yang tidak terikat dalam perkawinan.

Pengertian terbaru ini menjadi salah satu pasal yang kontroversi karena sebahagian masyarakat merasa Negara terlalu ikut campur ke dalam ranah pribadi masyarakat. Namun setelah melihat isi pasal berikutnya maka dapat diketahui lebih lanjut bahwa pasal ini termasuk dalam delik aduan. Hal ini karena ayat (2) pasal tersebut menyatakan bahwa tidak dapat dilakukan penuntutan kecuali atas pengaduan suami, istri, orang tua, atau anaknya yang dalam penjelasan pasal dikatakan anak dalam hal ini minimal berumur 16 (enam belas) tahun.

Setelah melihat kelanjutan pasal dan juga penjelasan aturannya, maka dapat ditarik kesimpulan bahwa suatu tindakan perzinahan tidak semudah itu untuk dilakukan penuntutan, tetap harus ada aduan dari pihak yang berpengaruh. 
Media Komunikasi dan Informasi Hukum dan Masyarakat

\section{KESIMPULAN DAN SARAN}

\section{A. Kesimpulan}

1. Aturan KUHP lama khususnya yang berkaitan dengan perzinahan tidak sesuai dengan budaya yang ada di Indonesia, sehingga seringkali perbuatan perzinahan yang sesungguhnya meresahkan masyarakat tidak dapat diadili sesuai dengan yang diharapkan, namun dalam perkembangan jaman saat ini banyak juga pihak yang beranggapan pengertian perzinahan dalam KUHP baru terlalu dalam masuk kedalam urusan pribadi masyarakat Indonesia mereka menganggap Negara harusnya tidak masuk sampai keranah sangat pribadi.

2. Perubahan dalam Kitab Undang Undang Hukum Pidana khususnya pasal mengenai perzinahan terbukti masih dapat efektif berjalan di masyarakat. Hal ini dikarenakan pasal ini masuk kedalam delik aduan. menyatakan bahwa tidak dapat dilakukan penuntutan kecuali atas pengaduan suami, istri, orang tua, atau anaknya yang dalam penjelasan pasal dikatakan anak dalam hal ini minimal berumur 16 (enam belas) tahun. Maka dapat dipahami bahwa suatu tindakan perzinahan tidak semudah itu untuk dilakukan penuntutan, tetap harus ada aduan dari pihak yang berpengaruh.

\section{B. Saran}

Segera disahkannya Revisi Kitab Undang-Undang Hukum Pidana (RKUHP) namun dalam hal ini telah dilakukan revisi yang sebaik-baiknya dengan juga mendengar saran dan pendapat masyarakat terutama dalam hal ini para pakar dalam bidang hukum.

\section{Daftar Bacaan}

Ali, Zainuddin, Hukum Pidana Islam, 2009, Jakarta : Sinar Grafika

Umar, Nasaruddin, 2015, Urgensi transformasi hukum Islam dalam pemajuan hak asasi manusia di Indonesia, hunafa : studi islamika

Hakim, Rahmat, 2000 Hukum Pidana Islam (Fiqh Jinayah), Bandung : Pustaka Setia

Koentjoroningrat, 1992, Metode-metode Penelitian Masyarakat, Jakarta : Gramedia

Ibrahim, Johnny, 2008, Teori dan Metodologi Penelitian Hukum Normatif, Malang : Bayumedia

Mahmud, Peter Marzuki, 2009, Penelitian Hukum, Jakarta : Prenada Media Group

Soekanto, Soerjono, 1984, Pengantar Penelitian Hukum, Jakarta : UI Press

Wardi, Ahmad Muslich, 2005, Hukum Pidana Islam, Jakarta : Sinar Grafika 